\title{
Uji Daya Hasil Pendahuluan Kandidat Jagung Hibrida Madura
}

\section{(Preliminary yield Trials on Madura hybrid Maize Candidates)}

\author{
Achmad Amzeri ${ }^{*}$, Deny Ardianzah ${ }^{1}$, Kaswan Badami $^{1}$, Achmad Djunedy ${ }^{1}$, dan Raden Achmad Sidqi Zaed Zaenollah Maskiyaqi ${ }^{1}$ \\ ${ }^{1}$ Pogram Studi Agroteknologi Fakultas Pertanian Universitas Trunojoyo Madura \\ Jalan Raya Telang, PO. BOX 2 Kamal, Bangkalan Madura 69162 \\ *Email korespondensi: aamzeri@gmail.com
}

Diterima 25 Februari 2019/Disetujui 01 Maret 2019

\begin{abstract}
Preliminary yield trials was conducted to determine yield potential of candidates variety compared to other varieties. The objectives of this study were to evaluate the character of three Madura hybrid maize candidates compared to 46 other genotypes tested. This research was conducted in Blega, Bangkalan District, Madura, from August to November 2017. The plant material used in this study were three Madura hybrid maize candidates $\left(G_{1}=M D R-3, G_{2}=M D R-4, G_{3}=M D R-5\right)$ and 46 maize genotypes (entries) as a comparison. This research used a Simple Lattice Design (7x7x2). Data were analyzed by F-test, then continued with Duncan's test $(\alpha=5 \%)$. The results showed that several plant characters from the 49 genotypes tested had significant differences except the characters weighing 100 seeds. Madura hybrid maize candidates $\left(G_{1}, G_{2}\right.$ and $\left.G_{3}\right)$ were very suitable to be developed in Madura because they had early maturity ( 84 days to 85 days) and high productivity (6.7 tons per hectare to 8.2 tons per hectare).
\end{abstract}

Key words : Preliminary yield trials, Madura hybrid maize candidates, early maturity, high productivity.

\begin{abstract}
ABSTRAK
Uji daya hasil pendahuluan dilakukan untuk mengetahui potensi hasil calon varietas dibandingkan dengan varietas lainnya. Tujuan penelitian ini adalah untuk mengevaluasi karakter tiga kandidat jagung hibrida Madura dibandingkan dengan 46 genotip lain yang diuji. Penelitian ini dilaksanakan di Kecamatan Blega Kabupaten Bangkalan Madura pada bulan Agustus sampai November 2017. Bahan tanaman yang digunakan dalam penelitian ini adalah tiga kandidat jagung hibrida Madura $\left(\mathrm{G}_{1}=\mathrm{MDR}-3\right.$, $\mathrm{G}_{2}=\mathrm{MDR}-4, \mathrm{G}_{3}=$ MDR-5) dan 46 genotip jagung (entri) sebagai pembanding. Penelitan ini menggunakan Rancangan Latis Sederhana $(7 \times 7 \times 2)$. Data dianalisis dengan uji-F, apabila terdapat pengaruh yang nyata dalam perlakuan maka dilakukan uji lanjut menggunakan uji Duncan's $(\alpha=5 \%)$. Hasil penelitian menunjukkan bahwa beberapa karakter tanaman dari 49 genotip yang diuji memiliki perbedaan yang nyata kecuali karakter bobot 100 biji. Kandidat jagung hibrida Madura $\left(G_{1}, G_{2}\right.$ dan $\left.G_{3}\right)$ sangat sesuai dikembangkan di Madura karena mempunyai umur pendek (84 hari sampai 85 hari) dan produktivitas tinggi (6.7 ton per hektar sampai 8,2 ton per hektar).
\end{abstract}

Kata kunci : Kandidat jagung hibrida Madura, Uji daya hasil pendahuluan, Umur genjah, Produktivitas tinggi.

\section{PENDAHULUAN}

Pulau Madura merupakan suatu pulau yang berada di wilayah Jawa Timur yang memiliki areal tanaman untuk jagung kurang lebih 300.000 hektar (30\% areal jagung di Jawa Timur), namun produktivitas ditingkat petani masih rendah rata-rata 2.1 ton per hektar (BPS, 2017). Hasil tersebut sangat rendah dibandingkan dengan daerah-daerah penghasil jagung lainnya. Rendahnya produktivitas jagung di pulau Madura disebabkan oleh rendahnya kesuburan tanah dan belum terakitnya jagung unggul untuk pulau Madura (Amzeri, 2018).

Rendahnya produksi jagung ditingkat petani tersebut disebabkan oleh kurang suburnya lahan, curah hujan yang cenderung rendah dan benih yang digunakan bukan hasil dari program pemuliaan (baik melalui seleksi atau hibridisasi) (Amzeri, 2009). Cara memecahkan permasalahan tersebut adalah (1) Memperbaiki lingkungan tempat tanaman tersebut tumbuh dan berkembang, (2) Merakit suatu varietas yang tahan terhadap cekaman lingkungan biotik maupun abiotik dan mempunyai potensi hasil tinggi yang dihasilkan melalui 
program pemuliaan (Amzeri, 2017). Cara kedua adalah metode yang populer untuk mendapat mengatasi permasalahan di atas (Amzeri, et al., 2011).

Pada tahun 2009 sampai tahun 2015, perakitan varietas jagung Hibrida berbasis jagung Madura telah dilakukan oleh tim peneliti Universitas Trunojoyo yang menghasilkan varietas MDR-3, MDR-4, MDR-5. Jagung Madura-3 yang akan dilepas, merupakan varietas hibrida silang tunggal yang merupakan persilangan antara galur jagung unggul madura yang ditemukan oleh peneliti Universitas Trunojoyo dan tetua jagung dari Balitsereal. Jagung Hibrida Madura-3 mempunyai produksi rata-rata 7 ton apabila ditanam di Madura, dan mempunyai umur kurang lebih dari 80 hari. Produksi yang tinggi dan umur yang genjah akan sangat sesuai apabila dikembangkan di Madura yang mempunyai curah hujan yang rendah. Selanjutnya jagung Madura-4 dan Madura-5 adalah jagung hibrida silang tiga jalur yang rata-rata hasilnya sekitar 7 ton per hektar (Amzeri, 2016; Amzeri, 2017). Hibrida silang tiga jalur ini dirakit untuk memperoleh produksi benih yang tinggi, sehingga harga benih hibrida akan lebih murah dan dijangkau oleh petani. Varietas-varietas di atas diharapkan mampu menigkatkan produktivitas jagung Madura, sehingga produktivitas jagung Jawa Timur dan Nasional akan meningkat.

Untuk melepas varietas diperlukan beberapa tahapan, yang tujuannya untuk mengetahui potensi hasil dan daya adaptasi serta stabilitas hasil dari varietas yang akan dilepas. Tahapan pertama yang harus dilakukan adalah uji pendahuluan yang dilanjutkan dengan uji daya hasil lanjutan (Wulandari dan Sugiharto, 2017). Berdasarkan hasil uji pendahuluan dan lanjutan, maka ditetapkan varietas yang layak untuk dijadikan entri dalam uji multilokasi.

\section{BAHAN DAN METODE}

Penelitian ini dilaksanakan di Kecamatan Blega Kabupaten Bangkalan Madura pada bulan Agustus sampai November 2017. Lokasi penelitian berada pada ketinggian $5 \mathrm{~m}$ dpl dengan jenis tanah grumosol. Bahan tanaman yang digunakan dalam penelitian ini adalah tiga kandidat jagung hibrida Madura (G1 = MDR-3, G2 = MDR-4, G3 = MDR-5) dan 46 genotip jagung (entri) sebagai pembanding. Pupuk yang digunakan adalah phonska dengan dosis $300 \mathrm{~kg} / \mathrm{ha}$ dan Urea dengan dosis $300 \mathrm{~kg} / \mathrm{ha}$. Pesitisida yang digunakan adalah Furadan 3G, Curacorn dan Saromyl 35 SD.

Penilitian ini menggunakan rancangan percobaan yang akan digunakan dalam penelitan ini menggunakan Rancangan Latis Sederhana $(7 \times 7 \times 2)$. Perlakuan terdiri dari 49 genotip tanaman jagung (tiga kandidat jagung hibrida Madura dan 46 genotip jagung pembanding). Parameter pengamatan dalam penelitian ini adalah tinggi tanaman, tinggi tongkol utama, umur berbunga dan umur panen, panjang tongkol, diameter tongkol, berat kering 100 biji, dan hasil produksi per hektar.

Uji $F$ digunakan untuk menganilisis pengaruh perlakuan. Apabila terdapat pengaruh yang nyata dalam perlakuan, maka dilakukan uji lanjut menggunakan Duncan's dengan taraf 5\%.

\section{HASIL DAN PEMBAHASAN}

Hasil rekapitulasi sidik ragam pada berbagai peubah yang diamati menunjukkan bahwa perlakuan genotip berpengaruh nyata terhadap tinggi tanaman, tinggi tongkol, umur berbunga, umur panen, diameter tongkol, panjang tongkol dan produksi perhektar, sedangkan pada parameter bobot 100 biji tidak berpengaruh nyata (Tabel 1). Selanjutnya pada Tabel 1 menunjukkan bahwa efektifitas rancangan latis terhadap RAK pada semua parameter seluruhnya berada di atas $100 \%$. Hal ini menunjukkan bahwa penggunaan Rancangan Latis sangat tepat dalam penelitian ini.

Tabel 1. Rekapitulasi KT, F-hitung, KK dan Efektif RAK peubah 49 genotip

\begin{tabular}{clllll}
\hline No & Peubah & KT & F-Hitung & KK $(\%)$ & Efektif RAK \\
\hline 1 & Tinggi tanaman & 179.93 & $17.32^{* *}$ & 3119224.10 & $104.96 \%$ \\
2 & Tinggi tongkol & 35.9 & $11.09^{* *}$ & 624861.38 & $110.20 \%$ \\
3 & Umur berbunga & 18.89 & $925.67 * *$ & 184311.22 & $156.98 \%$ \\
4 & Umur panen & 71.67 & $187.57 * *$ & 845000 & $109.75 \%$ \\
5 & Diameter tongkol & 0.06 & $4.74^{* *}$ & 2239.53 & $100.53 \%$ \\
6 & Panjang tongkol & 1.22 & $7.93 * *$ & 28518.86 & $108.68 \%$ \\
7 & Bobot 100 biji & 88484.08 & $1.69904^{\text {tn }}$ & 366764.31 & $100.01 \%$ \\
8 & Produksi perhektar & 0.88 & $41.77^{* *}$ & 4601.38 & $107.95 \%$ \\
\hline
\end{tabular}

Keterangan : KT $=$ Kuadrat Tengah; KK $=$ Koefesien Keragaman, $* *=$ berbeda nyata, $\mathrm{tn}=$ tidak nyata 
Tabel 2. Nilai tengah tinggi tanaman dan tinggi tonggol 49 genotip tanaman jagung

\begin{tabular}{|c|c|c|c|c|c|c|c|c|c|c|c|}
\hline \multirow{3}{*}{$\begin{array}{r}\text { No } \\
1\end{array}$} & \multirow{3}{*}{$\begin{array}{c}\text { Genotip } \\
\text { G-1 }\end{array}$} & \multicolumn{4}{|c|}{ Rerata } & \multirow{3}{*}{$\begin{array}{l}\text { No } \\
26\end{array}$} & \multirow{3}{*}{$\begin{array}{l}\text { Genotip } \\
\text { G-26 }\end{array}$} & \multicolumn{4}{|c|}{ Rerata } \\
\hline & & \multicolumn{2}{|c|}{ T. tanaman } & \multicolumn{2}{|c|}{ T. tongkol } & & & \multicolumn{2}{|c|}{ T. tanaman } & \multicolumn{2}{|c|}{ T. tongkol } \\
\hline & & 173.56 & $c-i$ & 77.69 & $a-i$ & & & 178.24 & $d-j$ & 79.78 & $b-i$ \\
\hline 2 & G-2 & 181.37 & e-k & 81.18 & $c-j$ & 27 & G-27 & 191.22 & $\mathrm{j}-1$ & 85.59 & $h-j$ \\
\hline 3 & G-3 & 179.14 & $\mathrm{~d}-\mathrm{k}$ & 80.18 & $b-i$ & 28 & G-28 & 167.23 & $b-e$ & 74.85 & $a-d$ \\
\hline 4 & G-4 & 191.09 & $\mathrm{j}-1$ & 85.53 & $h-j$ & 29 & G-29 & 168.31 & b-g & 75.34 & $\mathrm{a}-\mathrm{g}$ \\
\hline 5 & G-5 & 194.37 & $\mathrm{kl}$ & 87.00 & $\mathrm{Ij}$ & 30 & G-30 & 177.44 & $c-j$ & 79.42 & $b-i$ \\
\hline 6 & G-6 & 199.78 & 1 & 89.42 & $\mathrm{~J}$ & 31 & G-31 & 179.24 & $\mathrm{~d}-\mathrm{k}$ & 80.23 & $b-i$ \\
\hline 7 & G-7 & 151.69 & $\mathrm{a}$ & 67.90 & A & 32 & G-32 & 187.23 & h-1 & 83.80 & $g-j$ \\
\hline 8 & G-8 & 180.18 & $e-k$ & 80.65 & $b-j$ & 33 & G-33 & 191.89 & $\mathrm{j}-1$ & 85.89 & $h-j$ \\
\hline 9 & G-9 & 191.21 & $\mathrm{j}-\mathrm{k}$ & 85.59 & $h-j$ & 34 & G-34 & 167.45 & $b-f$ & 74.95 & $a-e$ \\
\hline 10 & G-10 & 185.76 & h-1 & 83.15 & $f-j$ & 35 & G-35 & 172.49 & $c-h$ & 77.21 & $a-i$ \\
\hline 11 & G-11 & 167.22 & b-e & 74.85 & $a-d$ & 36 & G-36 & 173.21 & $c-i$ & 77.53 & $a-i$ \\
\hline 12 & G-12 & 174.24 & $c-i$ & 77.99 & $b-i$ & 37 & G-37 & 183.29 & g-1 & 82.04 & $d-j$ \\
\hline 13 & G-13 & 185.23 & h-1 & 82.91 & $e-j$ & 38 & G-38 & 187.34 & h-1 & 83.85 & $g-j$ \\
\hline 14 & G-14 & 169.23 & b-g & 75.75 & $a-g$ & 39 & G-39 & 188.21 & $\mathrm{i}-1$ & 84.24 & $h-j$ \\
\hline 15 & G-15 & 176.34 & $c-j$ & 78.93 & $b-i$ & 40 & G-40 & 187.34 & h-l & 83.85 & $g-j$ \\
\hline 16 & G-16 & 177.48 & $c-j$ & 79.44 & $b-i$ & 41 & G-41 & 181.23 & $e-k$ & 81.12 & $c-j$ \\
\hline 17 & G-17 & 179.68 & e-k & 80.42 & $b-j$ & 42 & G-42 & 179.56 & e-k & 80.37 & $b-i$ \\
\hline 18 & G-18 & 180.12 & e-k & 80.62 & $b-j$ & 43 & G-43 & 180.63 & e-k & 80.85 & $b-j$ \\
\hline 19 & G-19 & 164.22 & $a-c$ & 73.50 & $\mathrm{Ab}$ & 44 & G-44 & 182.32 & $f-k$ & 81.61 & $d-j$ \\
\hline 20 & G-20 & 158.23 & $\mathrm{ab}$ & 70.82 & $\mathrm{~A}$ & 45 & G-45 & 180.21 & $e-k$ & 80.66 & $b-j$ \\
\hline 21 & G-21 & 172.58 & $c-h$ & 77.25 & $a-i$ & 46 & G-46 & 181.36 & $e-k$ & 81.18 & $d-j$ \\
\hline 22 & G-22 & 183.24 & g-k & 82.02 & $d-j$ & 47 & G-47 & 180.42 & $e-k$ & 80.76 & $b-j$ \\
\hline 23 & G-23 & 169.28 & b-g & 75.77 & $a-h$ & 48 & G-48 & 179.21 & $\mathrm{~d}-\mathrm{k}$ & 80.21 & $b-i$ \\
\hline 24 & G-24 & 165.32 & $a-c$ & 74.00 & $a-c$ & 49 & G-49 & 178.24 & $d-j$ & 79.78 & $b-i$ \\
\hline 25 & G-25 & 167.89 & $b-f$ & 75.15 & $a-f$ & & & & & & \\
\hline
\end{tabular}

Keterangan : Angka-angka yang diikuti huruf yang sama pada kolom yang sama menunjukkan tidak berbeda nyata berdasarkan uji Duncan's pada taraf 5\% 
Tabel 3. Nilai tengah umur berbunga dan umur panen 49 genotip tanaman jagung

\begin{tabular}{|c|c|c|c|c|c|c|c|c|c|c|c|}
\hline \multirow{3}{*}{$\begin{array}{r}\text { No } \\
1\end{array}$} & \multirow{3}{*}{$\begin{array}{c}\text { Genotip } \\
\text { G-1 }\end{array}$} & \multicolumn{4}{|c|}{ Rerata } & \multirow{3}{*}{$\begin{array}{c}\text { No } \\
26\end{array}$} & \multirow{3}{*}{$\begin{array}{l}\text { Genotip } \\
\text { G-26 }\end{array}$} & \multicolumn{4}{|c|}{ Rerata } \\
\hline & & \multicolumn{2}{|c|}{$\begin{array}{c}\text { Umur } \\
\text { berbunga }\end{array}$} & \multicolumn{2}{|l|}{$\begin{array}{l}\text { Umur } \\
\text { Panen }\end{array}$} & & & \multicolumn{2}{|c|}{$\begin{array}{c}\text { Umur } \\
\text { berbunga }\end{array}$} & \multicolumn{2}{|c|}{ Umur panen } \\
\hline & & 37.00 & $\mathrm{~b}$ & 84.00 & $\mathrm{~B}$ & & & 42.00 & $\overline{e-n}$ & 90.00 & $\mathrm{~d}-\mathrm{k}$ \\
\hline 2 & G-2 & 38.00 & $\mathrm{c}$ & 84.00 & B & 27 & G-27 & 41.50 & $e-i$ & 88.00 & $c-g$ \\
\hline 3 & G-3 & 39.00 & $\mathrm{~d}$ & 85.00 & bc & 28 & G-28 & 43.00 & $f-n$ & 92.00 & $e-n$ \\
\hline 4 & G-4 & 44.00 & $f-n$ & 95.00 & $g-n$ & 29 & G-29 & 46.00 & h-n & 98.00 & $j-n$ \\
\hline 5 & G-5 & 51.00 & k-n & 109.00 & $\mathrm{mn}$ & 30 & G-30 & 43.00 & $f-n$ & 92.00 & $e-n$ \\
\hline 6 & G-6 & 52.00 & $1-n$ & 110.00 & $\mathrm{n}$ & 31 & G-31 & 45.00 & g-n & 96.00 & h-n \\
\hline 7 & G-7 & 36.00 & $\mathrm{a}$ & 78.00 & $\mathrm{a}$ & 32 & G-32 & 43.00 & $f-n$ & 92.00 & $e-n$ \\
\hline 8 & G-8 & 40.00 & $\mathrm{e}$ & 86.50 & $b-f$ & 33 & G-33 & 46.00 & $h-n$ & 98.00 & $j-n$ \\
\hline 9 & G-9 & 50.00 & $j-n$ & 106.00 & $1--n$ & 34 & G-34 & 43.50 & $f-n$ & 92.00 & $e-n$ \\
\hline 10 & G-10 & 42.00 & e-n & 90.00 & d-h & 35 & G-35 & 44.00 & $f-n$ & 94.00 & $f-n$ \\
\hline 11 & G-11 & 43.00 & $f-n$ & 94.50 & $f-n$ & 36 & G-36 & 47.00 & $\mathrm{i}-\mathrm{n}$ & 100.00 & $k-n$ \\
\hline 12 & G-12 & 44.00 & $f-n$ & 94.00 & $f-n$ & 37 & G-37 & 42.00 & e-n & 90.00 & $d-1$ \\
\hline 13 & G-13 & 45.00 & $g-n$ & 96.00 & h-n & 38 & G-38 & 43.00 & $f-n$ & 92.00 & $e-n$ \\
\hline 14 & G-14 & 42.00 & e-n & 90.00 & $d-i$ & 39 & G-39 & 43.00 & $f-n$ & 90.00 & d-n \\
\hline 15 & G-15 & 43.00 & $f-n$ & 92.00 & e-n & 40 & G-40 & 41.00 & $e-h$ & 88.00 & $c-g$ \\
\hline 16 & G-16 & 44.00 & $f-n$ & 94.00 & $f-n$ & 41 & $\mathrm{G}-41$ & 40.50 & e-g & 86.00 & b-e \\
\hline 17 & G-17 & 45.00 & g-n & 96.00 & h-n & 42 & G-42 & 43.00 & $f-n$ & 92.00 & $e-n$ \\
\hline 18 & G-18 & 56.00 & $\mathrm{n}$ & 98.00 & $j-n$ & 43 & G-43 & 44.00 & $f-n$ & 94.00 & $f-n$ \\
\hline 19 & G-19 & 53.00 & $\mathrm{mn}$ & 92.00 & e-n & 44 & G-44 & 43.00 & $f-n$ & 92.00 & $e-n$ \\
\hline 20 & G-20 & 45.00 & g-n & 96.00 & h-n & 45 & G-45 & 42.00 & e-n & 90.00 & $d-n$ \\
\hline 21 & G-21 & 42.00 & $e-n$ & 90.00 & $d-j$ & 46 & G-46 & 45.00 & g-n & 96.00 & h-n \\
\hline 22 & G-22 & 41.00 & e-h & 88.00 & $c-g$ & 47 & G-47 & 46.00 & h-n & 97.00 & i-n \\
\hline 23 & G-23 & 40.00 & ef & 86.00 & $b-d$ & 48 & G-48 & 47.50 & $\mathrm{i}-\mathrm{n}$ & 100.00 & $\mathrm{k}-\mathrm{n}$ \\
\hline 24 & G-24 & 43.00 & $f-n$ & 92.00 & $e-n$ & 49 & G-49 & 43.00 & $f-n$ & 92.00 & $e-n$ \\
\hline 25 & G-25 & 44.00 & $f-n$ & 94.00 & $f-n$ & & & & & & \\
\hline
\end{tabular}

Keterangan : Angka-angka yang diikuti huruf yang sama pada kolom yang sama menunjukkan tidak berbeda nyata berdasarkan uji Duncan's pada taraf $5 \%$. 
Tabel 4. Nilai tengah diameter tongkol dan panjang tonggol 49 genotip tanaman jagung

\begin{tabular}{|c|c|c|c|c|c|c|c|c|c|c|c|}
\hline \multirow{3}{*}{$\begin{array}{r}\text { No } \\
1\end{array}$} & \multirow{3}{*}{$\begin{array}{c}\text { Genotip } \\
\text { G-1 }\end{array}$} & \multicolumn{4}{|c|}{ Rerata } & \multirow{3}{*}{$\begin{array}{l}\text { No } \\
26\end{array}$} & \multirow{3}{*}{$\begin{array}{l}\text { Genotip } \\
\text { G-26 }\end{array}$} & \multicolumn{4}{|c|}{ Rerata } \\
\hline & & \multicolumn{2}{|c|}{$\begin{array}{c}\text { Diameter } \\
\text { tongkol }\end{array}$} & \multicolumn{2}{|l|}{$\begin{array}{l}\begin{array}{l}\text { Panjang } \\
\text { tongkol }\end{array} \\
\end{array}$} & & & \multicolumn{2}{|c|}{$\begin{array}{c}\text { Diameter } \\
\text { tongkol }\end{array}$} & \multirow{2}{*}{\multicolumn{2}{|c|}{$\begin{array}{cc} & \begin{array}{c}\text { Ponjong } \\
\text { tongkol }\end{array} \\
17.22 & \mathrm{bc}\end{array}$}} \\
\hline & & 4.86 & $\mathrm{bc}$ & 17.92 & $\mathrm{bc}$ & & & 4.87 & $\mathrm{bc}$ & & \\
\hline 2 & G-2 & 4.89 & $\mathrm{bc}$ & 18.19 & $\mathrm{c}$ & 27 & G-27 & 4.87 & $\mathrm{bc}$ & 16.89 & $\mathrm{bc}$ \\
\hline 3 & G-3 & 4.74 & $\mathrm{ab}$ & 17.43 & $\mathrm{bc}$ & 28 & G-28 & 4.76 & $a b$ & 16.97 & $\mathrm{bc}$ \\
\hline 4 & G-4 & 4.91 & $\mathrm{bc}$ & 18.87 & $\mathrm{c}$ & 29 & G-29 & 4.56 & $a b$ & 16.79 & $\mathrm{bc}$ \\
\hline 5 & G-5 & 5.06 & $\mathrm{bc}$ & 19.17 & $\mathrm{c}$ & 30 & G-30 & 4.87 & $\mathrm{bc}$ & 16.34 & $\mathrm{~b}$ \\
\hline 6 & G-6 & 5.23 & $\mathrm{c}$ & 17.31 & $\mathrm{bc}$ & 31 & G-31 & 4.65 & $a b$ & 16.23 & $a b$ \\
\hline 7 & G-7 & 4.35 & $\mathrm{a}$ & 14.71 & $\mathrm{a}$ & 32 & G-32 & 4.65 & $a b$ & 16.86 & $\mathrm{bc}$ \\
\hline 8 & G-8 & 4.56 & $a b$ & 15.96 & $a b$ & 33 & G-33 & 4.76 & $a b$ & 16.23 & $a b$ \\
\hline 9 & G-9 & 4.52 & $a b$ & 16.06 & $a b$ & 34 & G-34 & 4.78 & $\mathrm{bc}$ & 16.65 & $\mathrm{bc}$ \\
\hline 10 & G-10 & 4.34 & $\mathrm{a}$ & 16.73 & $\mathrm{bc}$ & 35 & G-35 & 4.56 & $a b$ & 16.23 & $a b$ \\
\hline 11 & G-11 & 4.56 & $a b$ & 16.78 & $\mathrm{bc}$ & 36 & G-36 & 4.92 & $\mathrm{bc}$ & 16.78 & $\mathrm{bc}$ \\
\hline 12 & G-12 & 4.87 & $\mathrm{bc}$ & 16.87 & $\mathrm{bc}$ & 37 & G-37 & 4.82 & $\mathrm{bc}$ & 16.34 & $\mathrm{bc}$ \\
\hline 13 & G-13 & 4.89 & $\mathrm{bc}$ & 17.21 & $\mathrm{bc}$ & 38 & G-38 & 4.76 & $a-c$ & 17.21 & $\mathrm{bc}$ \\
\hline 14 & G-14 & 4.98 & $\mathrm{bc}$ & 17.44 & $\mathrm{bc}$ & 39 & G-39 & 4.87 & $\mathrm{bc}$ & 17.34 & $\mathrm{bc}$ \\
\hline 15 & G-15 & 4.78 & $a-c$ & 17.51 & $\mathrm{bc}$ & 40 & G-40 & 4.67 & $a b$ & 16.65 & $\mathrm{bc}$ \\
\hline 16 & G-16 & 4.87 & $\mathrm{bc}$ & 16.98 & $\mathrm{bc}$ & 41 & G-41 & 4.89 & $\mathrm{bc}$ & 16.87 & $\mathrm{bc}$ \\
\hline 17 & G-17 & 4.99 & $\mathrm{bc}$ & 17.21 & $\mathrm{bc}$ & 42 & G-42 & 4.89 & $\mathrm{bc}$ & 17.56 & $\mathrm{bc}$ \\
\hline 18 & G-18 & 4.78 & $a-c$ & 17.23 & $\mathrm{bc}$ & 43 & $\mathrm{G}-43$ & 4.65 & $a b$ & 16.67 & $\mathrm{bc}$ \\
\hline 19 & G-19 & 4.67 & $\mathrm{ab}$ & 16.87 & $\mathrm{bc}$ & 44 & $\mathrm{G}-44$ & 4.87 & $\mathrm{bc}$ & 16.89 & $\mathrm{bc}$ \\
\hline 20 & G-20 & 4.78 & $a-c$ & 18.78 & $\mathrm{c}$ & 45 & G-45 & 4.54 & $a b$ & 17.21 & $\mathrm{bc}$ \\
\hline 21 & G-21 & 4.89 & $\mathrm{bc}$ & 17.01 & $\mathrm{bc}$ & 46 & G-46 & 4.86 & $\mathrm{bc}$ & 16.89 & $\mathrm{bc}$ \\
\hline 22 & G-22 & 4.89 & $\mathrm{bc}$ & 17.21 & $\mathrm{bc}$ & 47 & G-47 & 4.88 & $\mathrm{bc}$ & 16.56 & $\mathrm{bc}$ \\
\hline 23 & G-23 & 4.76 & $a b$ & 17.56 & $\mathrm{bc}$ & 48 & G-48 & 4.89 & $\mathrm{bc}$ & 16.78 & $\mathrm{bc}$ \\
\hline 24 & G-24 & 4.67 & $a b$ & 17.23 & $\mathrm{bc}$ & 49 & G-49 & 4.87 & $\mathrm{bc}$ & 16.56 & $\mathrm{bc}$ \\
\hline 25 & G-25 & 4.76 & $a b$ & 17.23 & $\mathrm{bc}$ & & & & & & \\
\hline
\end{tabular}

Keterangan : Angka-angka yang diikuti huruf yang sama pada kolom yang sama menunjukkan tidak berbeda nyata berdasarkan uji Duncan's pada taraf 5\% 
Tabel 5. Nilai tengah produksi perhektar 49 genotip tanaman jagung

\begin{tabular}{|c|c|c|c|c|c|c|c|}
\hline No & Genotip & & rata & No & Genotip & & Rerata \\
\hline 1 & G-1 & 7.10 & e-1 & 26 & G-26 & 6.83 & $d-1$ \\
\hline 2 & G-2 & 8.20 & $\mathrm{n}$ & 27 & G-27 & 6.56 & c-1 \\
\hline 3 & G-3 & 6.70 & $d-1$ & 28 & G-28 & 6.89 & $d-1$ \\
\hline 4 & G-4 & 6.71 & $\mathrm{~d}-1$ & 29 & G-29 & 6.56 & $\mathrm{c}-1$ \\
\hline 5 & G-5 & 7.80 & $1-n$ & 30 & G-30 & 7.23 & $h-m$ \\
\hline 6 & G-6 & 7.91 & $\mathrm{mn}$ & 31 & G-31 & 7.21 & $g-1$ \\
\hline 7 & G-7 & 3.80 & $\mathrm{a}$ & 32 & G-32 & 6.89 & d-1 \\
\hline 8 & G-8 & 5.67 & $\mathrm{~b}$ & 33 & G-33 & 6.98 & d-1 \\
\hline 9 & G-9 & 6.21 & $b-d$ & 34 & G-34 & 7.02 & $d-1$ \\
\hline 10 & G-10 & 6.45 & $\mathrm{c}-\mathrm{k}$ & 35 & G-35 & 6.76 & $d-1$ \\
\hline 11 & G-11 & 7.23 & $\mathrm{~g}-\mathrm{m}$ & 36 & G-36 & 6.23 & b-e \\
\hline 12 & G-12 & 7.42 & $\mathrm{i}-\mathrm{m}$ & 37 & G-37 & 6.34 & $c-h$ \\
\hline 13 & G-13 & 6.34 & $\mathrm{c}-\mathrm{g}$ & 38 & G-38 & 6.23 & $b-f$ \\
\hline 14 & G-14 & 6.89 & $d-1$ & 39 & G-39 & 6.34 & $c-i$ \\
\hline 15 & G-15 & 7.42 & $j-m$ & 40 & G-40 & 6.44 & $c-j$ \\
\hline 16 & G-16 & 7.54 & $k-n$ & 41 & G-41 & 6.98 & d-1 \\
\hline 17 & G-17 & 7.23 & $h-m$ & 42 & G-42 & 6.78 & $d-1$ \\
\hline 18 & G-18 & 7.23 & h-m & 43 & G-43 & 6.98 & $d-1$ \\
\hline 19 & G-19 & 6.89 & d-1 & 44 & G-44 & 5.98 & $\mathrm{bc}$ \\
\hline 20 & G-20 & 6.88 & $d-1$ & 45 & G-45 & 6.78 & d-1 \\
\hline 21 & G-21 & 6.87 & d-1 & 46 & G-46 & 6.54 & c-1 \\
\hline 22 & G-22 & 6.78 & d-1 & 47 & G-47 & 7.23 & h-m \\
\hline 23 & G-23 & 7.21 & $f-1$ & 48 & G-48 & 7.34 & h-m \\
\hline 24 & G-24 & 7.22 & g-m & 49 & G-49 & 7.21 & g-m \\
\hline 25 & G-25 & 7.34 & h-m & & & & \\
\hline
\end{tabular}

Keterangan : Angka-angka yang diikuti huruf yang sama pada kolom yang sama menunjukkan tidak berbeda nyata berdasarkan uji Duncan's pada taraf 5\%

Tinggi tanaman, tinggi tongkol, umur berbunga dan umur panen

Pengamatan tinggi tanaman dan tinggi tongkol dilakukan pada saat tanaman memasuki fase generatif, yang ditandai dengan munculnya tassel (bunga jantan) pada tanaman jagung. Kandidat jagung Hibrida Madura $\left(\mathrm{G}_{1}, \mathrm{G}_{2}\right.$ dan $\left.\mathrm{G}_{3}\right)$ mempunyai tinggi tanaman berkisar antara $173.56 \mathrm{~cm}$ sampai $179.14 \mathrm{~cm}$. Kandidat jagung hibrida $G_{1}$ mempunyai tinggi tanaman yang lebih pendek, namun tidak berbeda nyata dengan kandidat hibrida madura lainnya $\left(\mathrm{G}_{2}\right.$ dan $\left.\mathrm{G}_{3}\right)$. Tinggi tanaman tertinggi dihasilkan pada $\mathrm{G}_{5}=194.37 \mathrm{~cm}$, namun tidak berbeda nyata dengan kandidat $\mathrm{G}_{2}$ dan $\mathrm{G}_{3}$, sedangkan tinggi tanaman terpendek dihasilkan pada $\mathrm{G}_{7}=151.69 \mathrm{~cm}$ dan berbeda nyata dengan tiga kandidat jagung hibrida Madura.

Kandidat jagung Hibrida Madura $\left(\mathrm{G}_{1}, \mathrm{G}_{2}\right.$ dan $\left.\mathrm{G}_{3}\right)$ mempunyai tinggi tongkol berkisar antara $77.69 \mathrm{~cm}$ sampai $81.18 \mathrm{~cm}$. Kandidat jagung hibrida $\mathrm{G}_{1}$ mempunyai tinggi tongkol yang lebih pendek, namun tidak berbeda nyata dengan kandidat hibrida madura lainnya $\left(\mathrm{G}_{2}\right.$ dan $\left.\mathrm{G}_{3}\right)$. Tinggi tongkol tertinggi dihasilkan pada $\mathrm{G}_{6}=89.42 \mathrm{~cm}$ ), namun tidak berbeda nyata dengan kandidat $\mathrm{G}_{2}$. Tinggi tongkol terpendek dihasilkan pada $\mathrm{G}_{7}=67.90 \mathrm{~cm}$, namun tidak berbeda nyata dengan kandidat $\mathrm{G}_{1}$.

Umur berbunga (umur muncul tassel) dapat mempengaruhi umur panen jagung. Menurut Umar (2008), umur berbunga berkorelasi positif dengan umur panen tanaman, di 
mana genotip yang mempunyai umur berbunga pendek akan mempunyai umur panen yang pendek. Umur berbunga kandidat jagung hibrida Madura berkisar antara 37 hari sampai 39 hari. Umur berbunga kandidat jagung Hibrida Madura berbeda nyata di antara ketiga kandidat. Umur berbunga terpanjang didapatkan pada $\mathrm{G}_{6}=52$ hari dan berbeda nyata dengan tiga kandidat jagung hibrida Madura. Umur berbunga terpendek didapatkan pada $\mathrm{G}_{7}=$ 36 hari dan berbeda nyata dengan tiga kandidat jagung hibrida Madura. Umur panen tiga kandidat jagung hibrida Madura berkisar antara 84 sampai 85 hari dan tidak berbeda nyata di antara ketiga kandidat. Umur panen terpanjang didapatkan pada G6 = 110 hari dan berbeda nyata dengan tiga kandidat jagung hibrida Madura. Umur panen terpendek didapatkan pada G7 = 78 hari dan berbeda nyata dibandingkan 3 kandidat jagung hibrida Madura.

\section{Diameter tongkol, panjang tongkol dan produksi per hektar}

Diameter tongkol kandidat jagung hibrida Madura berkisar antara $4.74 \mathrm{~cm}$ sampai $4.89 \mathrm{~cm}$. Diameter tongkol kandidat jagung hibrida madura tidak berbeda nyata di antara ketiga kandidat jagung hibrida Madura. Diameter tongkol tertinggi didapatkan pada $\mathrm{G}_{6}=5.23 \mathrm{~cm}$, namun tidak berbeda nyata dengan dua kandidat jagung hibrida Madura $\mathrm{G}_{1}$ dan $\mathrm{G}_{2}$. Diameter tongkol terendah didapatkan pada $G_{7}=4.35 \mathrm{~cm}$, namun tidak berbeda nyata dengan kandidat jagung hibrida Madura $\mathrm{G}_{3}$. Panjang tongkol Kandidat jagung hibrida Madura berkisar antara $17.43 \mathrm{~cm}$ sampai $18.19 \mathrm{~cm}$. Panjang tongkol jagung hibrida Madura tidak berbeda nyata di antara ketiga kandidat. Panjang tongkol terpanjang didapatkan pada $\mathrm{G}_{5}=$ $19.17 \mathrm{~cm}$, namun tidak berbeda nyata dengan tiga kandidat jagung hibrida Madura. Panjang tongkol terpendek didapatkan pada $\mathrm{G}_{7}=14.71 \mathrm{~cm}$ dan berbeda nyata dibandingkan tiga kandidat jagung hibrida Madura.

Produksi per hektar tiga kandidat jagung hibrida Madura berkisar 6.70 ton/hektar sampai 8.20 ton/hektar. Kandidat $\mathrm{G}_{2}$ (8.20 ton/hektar) mempunyai produksi per hektar tertinggi diantara semua genotip yang diuji dan berbeda nyata diantara kedua kandidat jagung hibrida Madura lainnya $\left(\mathrm{G}_{1}\right.$ dan $\left.\mathrm{G}_{3}\right)$. Produksi per hektar terendah didapatkan pada $\mathrm{G}_{7}=3.80$ ton/hektar dan berbeda nyata dibandingkan dengan tiga kandidat jagung hibrida Madura.

\section{Penampilan kandidat jagung hibrida Madura dengan genotip lain}

Jagung yang akan dikembangkan di Madura harus mempunyai umur panen genjah dan produksi yang tinggi (Amzeri, 2017). Karakter umur pendek dan produksi tinggi merupakan karakter yang menjadi perhatian utama karena bulan hujan di Madura berkisar 3 sampai 4 bulan di Madura bagian timur (Pamekasan dan Sumenep) (Sigit, et al., 2016) dan produktivitas jagung di Madura sangat rendah.
Berdasarkan umur panen jagung dibagi menjadi tiga kelompok yaitu (1) berumur pendek atau genjah (75-95 hari), (2) berumur sedang (95-120 hari), dan (3) berumur panjang (lebih dari 120 hari) (Azrai, 2013). Kandidat jagung hibrida Madura mempunyai umur panen berkisar 84-85 hari, sehingga merupakan jagung berumur genjah. Jagung $G_{7}$ merupakan genotip berumur pendek (78 hari), di mana genotip ini adalah jagung lokal Madura yang digunakan sebagai varietas pembanding jagung berumur genjah. Produksi per hektar kandidat jagung hibrida Madura berkisar antar 6.7 ton per hektar sampai 8.2 ton per hektar. Produktivitas ini sudah meningkat $76 \%$ sampai $116 \%$ dibandingkan jagung lokal Madura $\left(\mathrm{G}_{7}\right)$.

Kandidat jagung hibrida Madura mempunyai potensi dikembangkan di Madura karena mempunyai karakter yang sesuai dengan kondisi lingkungan di Madura (berumur pendek dan produktivitas tinggi). Pengembangan jagung umur genjah dan produksi tinggi di Madura akan meningkatkan produktivitas jagung di Madura dan Nasional.

\section{KESIMPULAN}

Hasil penelitian menunjukkan bahwa beberapa karakter tanaman dari 49 genotip yang diuji memiliki perbedaan yang nyata kecuali karakter bobot 100 biji. Kandidat jagung hibrida Madura $\left(\mathrm{G}_{1}, \mathrm{G}_{2}\right.$ dan $\left.\mathrm{G}_{3}\right)$ sangat sesuai dikembangkan di Madura karena mempunyai umur pendek (84 hari sampai 85 hari) dan produktivitas tinggi (6.7 ton per hektar sampai 8.2 ton per hektar).

\section{DAFTAR PUSTAKA}

Amzeri, A. 2009. Parameter Genetik Lima Jagung Lokal Madura. Jurnal Agrovigor. 2(2) : 18-26.

Amzeri, A. D. Indradewa, B.S. Daryono, D. Rachmawati. 2011. Kekerabatan Jagung (Zea mays L.) Lokal Madura Berdasarkan Karakter Morfologi dan Penanda RAPD. Biota. 16(2):227-235.

Amzeri, A. 2016. Evaluasi Nilai Heterosis dan Heterobeltiosis pada Persilangan Dialel Tanaman Jagung Madura (Zea mays L.). Jurnal Agrosains : Karya Kreatif dan Inovatif. 3(2):286-295.

Amzeri, A. 2017. Uji Daya Hasil 10 Hibrida Harapan Jagung Madura Berdaya Hasil Tinggi dan Berumur Genjah. Jurnal Agrovigor. 10(1):73-79.

Amzeri, A. 2018. Tinjauan Perkembangan Pertanian Jagung di Madura dan Alternatif Pengolahan Menjadi Biomaterial. Rekayasa. 11(1):74-86.

Azrai, M. 2013. Jagung Hibrida Genjah: Prospek Pengembangan Menghadapi Perubahan Iklim. IPTEK Tanaman Pangan. 8(2):90-96. 
BPS, 2017. Produktivitas Jagung Jawa Timur. http://jatim.bps.go.id/tgl 23 November 2018.

Sigit, R., L.D. Wulandari, H. Santoso. 2016. Ekspresi Lanskap-Agrikultur dan Pola Pemukiman Masyarakat Peladang di Madura Timur. Jurnal Ruas. 14(1):11-23.
Umar, S. 2008. Variasi genetic, heritabilitas. dan korelasi genotipik sifat-sifat penting tanaman wijen (Sesamum indicum L.). J. Littri. 13:88-92.

Wulandari, D.R., A.N. Sugiharto. 2017. Uji Daya Hasil Pendahuluan Beberapa Galur Jagung Manis (Zea mays L. Saccharata). Jurnal Produksi Tanaman. 5(12):19982007. 